\title{
Adapting to an unprecedented scenario: surgery during the COVID-19 outbreak
}

\section{Adaptação a um cenário sem precedente: cirurgia durante o surto de COVID-19}

Carlos Yánez Benítez ${ }^{1}$; Ana Nogués PeDival 2 ; Issa Talal ${ }^{2}$; Beatriz Cros²; Marcelo Fontenelle Ribeiro Junior ${ }^{3}$ (DD; Mohammad Azfar ${ }^{4}$; Salomone Di SaVerio5; Juan Luis Blas Laina².

\begin{abstract}
A B S T R A C T
On January 30th, 2020, the World Health Organization declared the Severe Acute Respiratory Syndrome 2 (SARSCoV-2) outbreak an international public health emergency, and one day later, the first COVID-19 case was confirmed in Gomera Island, Spain. In the following weeks, the number of cases in several Spanish cities spiked alarmingly, with thousands reported. This new coronavirus outbreak generated unprecedented changes in the Surgery Departments around the world, first in Asia, followed weeks later in Europe and America. This novel scenario of health crisis demanded a change in logistics and organization to guarantee urgent operations onCOVID-19 cases without interrupting the capability to handle emergency and oncologic surgery in the virus-free population, minimizing the viral transmission to staff and other patients. This manuscript aims to summarize the changes adopted by the General and GI Surgery Departments to address this unprecedented clinical scenario, including the restructuring of surgical schedules, staff preparation, and the departments outbreak response protocols and recommendations for surgical techniques and risk management.
\end{abstract}

Keywords: Pandemics. Coronavirus. Coronavirus Infections. Surgicenters. Personal Protective Equipment.

\section{INTRODUCTION}

In December of 2019, several cases of pneumonia of unknown etiology were diagnosed in the city of Wuhan, China. One week later, the causative agent was recognized and named Severe Acute Respiratory Syndrome Coronavirus 2 (SARS-CoV-2), and the disease designated as COVID-19'. In January of 2020, the SARS-CoV-2 epidemic had reached Europe, affecting initially northern Italy, and Spain soon after. On the 26th of February, the first case was reported in São Paulo, Brazil2, and by the beginning of April, South America had been severely impacted by COVID-193. In response to this fast-growing threat, the global surgical community had to make rapid changes. COVIDCrisis Management Teams (C-CMT) were created, and COVID-19 coordinators designated in the Surgery Departments (SD-CC). Initially, there were no standard guidelines, so the C-CMT followed international World Health Organization (WHO) recommendations. During the pandemic development, these measures were adopted to the framework of each country's guidelines for surgical treatment of patients with COVID-194-7, and measures adopted to reduce the risk of SARS-CoV-2 contamination of surgical teams with the laparoscopic approach $^{8}$.

\section{OBJECTIVE}

This manuscript aims to describe the changes adopted globally by the Surgery Departments in preparation for this unprecedented scenario, and it

1 - Royo Villanova Hospital, General and GI Surgery - Zaragoza - Zaragoza - Espanha 2 - Royo Villanova Hospital, General and GI Surgery - Zaragoza - Zaragoza - Espanha 3 - PUC Sorocaba, Pós-Graduação IAMSPE e Hospital Moriah, Cirurgia Geral e Trauma - São Paulo - SP - Brasil 4 - Al Rahba Hospital, General Surgery - Abu Dahbi - UAE 5 - University of Insubria, General Surgery - Varese - Varese - Itália 
describes the measures embraced both by the C-CMT and the SD-CC of surgical departments to prepare for the COVID-19 pandemic, focusing on how to optimize patient care and prevent healthcare workers from SARSCoV-2 infection.

\section{METHODS}

Updated research of original publications, world health organizations' recommendations, and surgical societies' clinical practice guidelines was carried out from March to May of 2020. The research focused on three objectives: operating room (OR) facilities preparations to care for suspected or confirmed COVID-19 patients, measures for reducing in-hospital transmission, and team organization to maintain the department's capacity for emergency surgeries and oncologic cases. This document aims to describe the changes adopted globally by the Surgery Departments in preparation for this unprecedented scenario. They include those related to personal protection equipment (PPE), specific OR arrangements and precautions, and changes in surgical technique protocols.

\section{RESULTS}

A total of 4 health agency documents were selected, two from the World Health Organization (WHO), one from the Centers for Disease Control and Prevention $(C D C)$, and one from the United States Environmental Protection Agency (US-EPA). Clinical practice guidelines from the American College of Surgeons (ACS), Royal College of Surgeons (RCS), and Spanish Surgical Association (AEC) were included as well in the review and also 12 original articles.

\section{RECOMMENDATIONS}

\section{Departmental changes and rescheduling}

The first steps taken by C-CMT were to issue infection prevention measures for staff members through the hospital websites and to communicate guidelines for task allocation and optimum use of the limited PPE supplies. All visits to admitted patients were restricted, and phone calls used to update family members about the patients' outcomes ${ }^{9}$. The SD-CC made task assignment adjustments and organized trimmed working teams to minimize staff members with unnecessary exposure. Among the early decisions made was the cancellation of elective surgeries and in-person external consultation and the temporary suspension of the Day Surgery program. To avoid interruption of care with patients programmed for a surgical followup consultation, a telephone or online approach was adopted. The SD-CC set priorities regarding staff and other resources assignment for oncological and urgent surgeries. Before these, all patients were screened using a standard symptoms questionnaire and a polymerase chain reaction (PCR) test to rule out COVID-19. Communication among staff members, case discussions, shifts, and morning handovers were modified to telematic meetings, promoting social distancing within the workspace. The hospitals' Intensive Care Unit (ICU) capacity was increased, modifying the Post-Anesthesia Care Unit (PACU) as an improvised Intensive Care Unit (ICU).

\section{Donning and doffing PPE}

Following the recommended guidelines, regular use of PPE was implemented for all those caring for suspected or confirmed COVID-19 cases, as well as for all emergency surgical procedures. The standard operating room PPE consisted of double gloving, surgical goggles, face shield, N95/FFP3 masks, protective surgical gown, and shoe covers in all the procedures $^{10,11}$. Due to the mask shortage, extended use protocols were implemented, and respirators were often used during the entire shift ${ }^{12}$. Surgical goggles and face shields were reutilized after cleansing with a 0,1\% sodium hypochlorite solution ${ }^{13}$. A checklist protocol for operating room staff was developed for adequate donning and doffing techniques, and training sessions were also implemented to avoid viral self-contamination. Even though both procedures are equally important due to the nature of the risk involved, an improper sequence in the latter can be a high-risk procedure ${ }^{14}$. Phan et al., in 2019 , reported that up to $90 \%$ of staff did not use a correct doffing technique ${ }^{15}$. To avoid errors, a specific 
area was assigned, equipped with a mirror for assisting staff members during the donning and doffing process. When operating as a team, a buddy-check was adopted, but when working individually, the surgeon could perform self-image checks on procedure compliance ${ }^{16}$. After doffing for surgical procedures on COVID-19 cases, the staff showered and changed to clean scrubs.

\section{Operating room precaution}

ORs and recovery areas were designated for suspected or confirmed COVID-19 cases, different from those in use for non-COVID-19 patients. The surgical team and OR staff equipped with PPE (Figure 1a). In the COVID-19 operating room essential apparatus was protected with plastic wrappings, and unnecessary equipment removed ${ }^{17,18}$. (Figures $1 b-1 c$ ). Alert signs were placed in the ORs to warn personnel to take the necessary precautions during COVID-19 procedures. Equipment and material necessary for the surgery were pre-packed in kits, and doors were kept shut to avoid staff traffic and virus spread within the OR complex. Patient charting was kept electronically preventing the use of paper charts inside the $O R$, and the number of staff involved in the procedure was limited ${ }^{8}$. After each operation on COVID-19 cases, single-use equipment and PPE were disposed of using red biohazard identified bags, and the OR cleaned with sodium hypochlorite solution.

\section{Surgical technique}

All emergency surgery was considered as suspected COVID-19, and a chest x-ray was done to rule out the presence of bilateral nodular and peripheral ground-glass opacities. For those who needed an abdominal CT-scan as part of their diagnostic workup, a chest CT-scan was also added ${ }^{19}$. The surgical team and staff used PPE for suspected or confirmed COVID-19 patients. The decision to make an open vs. laparoscopic approach depended on the clinical judgment of the surgical team. For confirmed COVID-19 cases, the surgical procedure was kept as simple as possible, avoiding extended, complicated techniques. In the laparoscopic approach, additional precautions were taken to avoid pneumoperitoneum leaks. The number of trocars was limited, preferring ballooned trocars, and when they were not used, the incision was minimal, allowing a tight fit and avoiding the escape of pneumoperitoneum. Pneumoperitoneum pressure used was between 8-11 $\mathrm{mmHg}$, and the intensity of the electrosurgical units kept low, avoiding the use of ultrasonic shears. All the pneumoperitoneum was evacuated through a smoke filtering system before surgical specimen extraction.

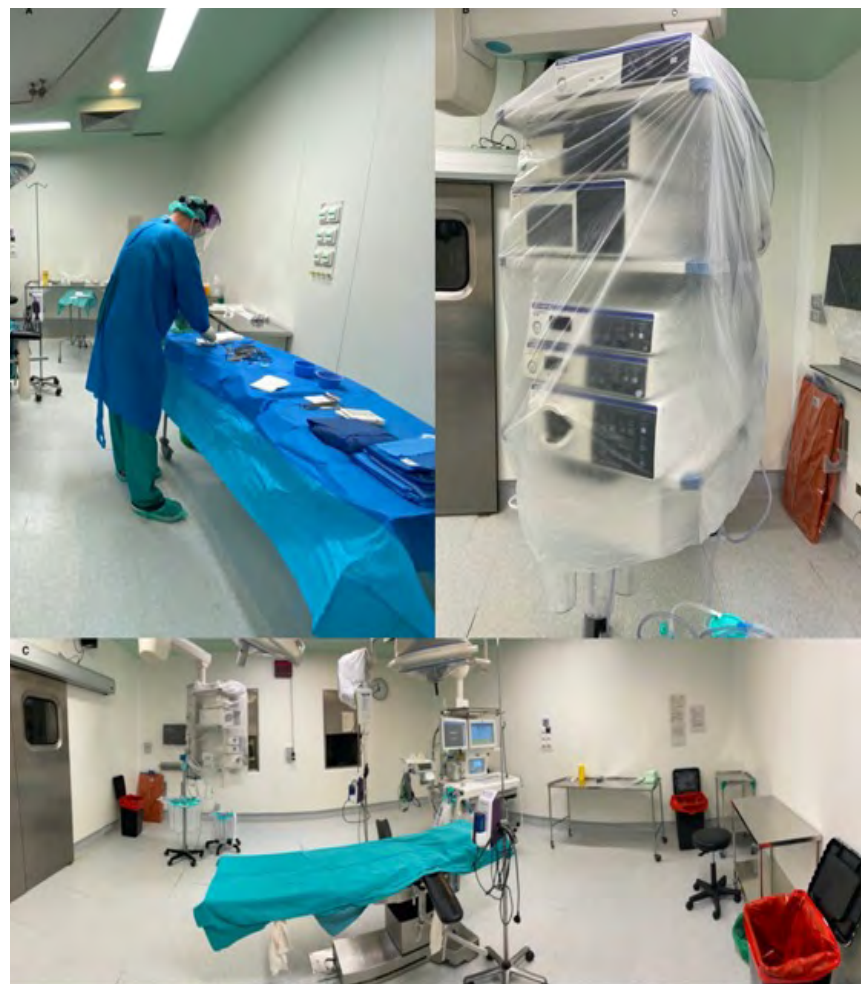

Figure 1. a. OR staff equipped with PPE.

b. Laparoscopic tower protected with plastic wrapping.

c. COVID-19 operating room with unnecessary equipment removed.

\section{Laparoscopy pneumoperitoneum filtration system}

Laparoscopic procedures in COVID-19 patients have the risk of spreading SARS-CoV-2 to the OR, exposing staff to virus transmission. This phenomenon may occur at the end of the surgery when evacuating the pneumoperitoneum or during specimen extraction. This hazardous situation was solved by designing pneumoperitoneum and surgical smoke filtering systems ${ }^{20}$. Figure 2 illustrates a system devised with standard suction tubing, a laparoscopic smoke filter, and a 2-liter suction bag filled with water and sodium hypochlorite ${ }^{21}$. 
This system created a sealed, leak-proof suction unit connected to the central OR vacuum, avoiding exposure of both, surgical team members and OR staff (Figure 2).

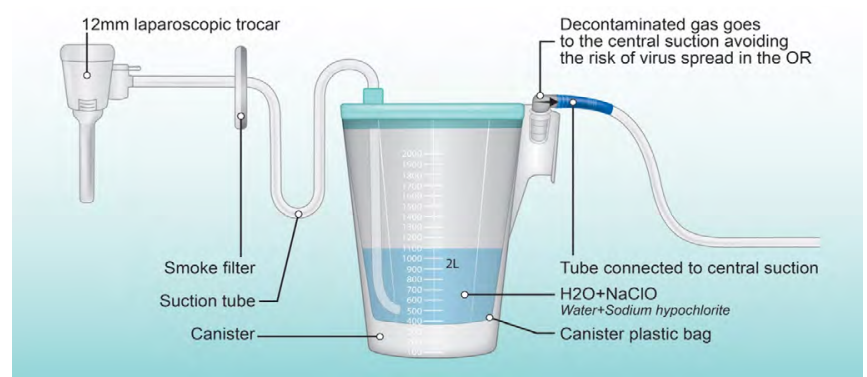

Figure 2. Diagram of the pneumoperitoneum filtration system improvised with common OR equipment.

\section{CONCLUSIONS}

The current COVID-19 pandemic has imposed global changes in team dynamics, department workload organization, personal protective equipment measures, and facilities preparedness. These unprecedented challenges must be swiftly adopted in our departments incorporating world health organizations and surgical society recommendations to our institutional guidelines. The lessons learned from this challenging experience should help the global surgical community prepare for a possible second wave of the pandemic and future similar scenarios.

\title{
R E S U M O
}

\begin{abstract}
Em 30 de janeiro de 2020, a Organização Mundial da Saúde declarou o surto de Síndrome Respiratória Aguda Grave 2 (SARS-CoV-2) emergência internacional de saúde pública e, um dia depois, o primeiro caso COVID-19 foi confirmado na Ilha Gomera, na Espanha. Nas semanas seguintes, o número de casos em várias cidades espanholas aumentou de forma alarmante, com milhares de casos sendo relatados. Esse novo surto de coronavírus gerou mudanças sem precedentes nos departamentos de cirurgia em todo o mundo, primeiro na Ásia, seguido semanas depois na Europa e na América. Esse novo cenário de crise na saúde exigiu mudança na logística e na organização para garantir as operações de urgência nos casos COVID-19, sem interromper a capacidade de lidar com cirurgias oncológicas e de emergência, da população livre de vírus, minimizando a transmissão viral para as equipes e outros pacientes. O objetivo deste trabalho é apresentar de forma resumida as mudanças adotadas pelos departamentos de cirurgia geral e gastrointestinal para abordar esse cenário clínico sem precedentes. Este, inclui a reestruturação dos horários cirúrgicos, a preparação da equipe, os protocolos e as recomendações de resposta a surtos, assim como as recomendações de técnicas cirúrgicas e manejo de riscos.
\end{abstract}

Palavras chave: Pandemia. Coronavírus. Infecções por Coronavírus. Centros Cirúrgicos. Equipamento de Proteção Individual.

\section{REFERENCES}

1. Lu H, Stratton CW, Tang YW. Outbreak of pneumonia of unknown etiology in Wuhan, China: The mystery and the miracle. J Med Virol. 2020;92(4):401-402. doi:10.1002/jmv.25678

2. Horwitz L, Nagovitch P, Sonnel HK, Zissis C. "Where Is the Coronavirus in Latin America?". AS/COA. Archived from the original on 22 March 2020. Available from: https://www.as-coa.org/articles/where-coronaviruslatin-america

3. Pan American Health Organization / World Health Organization. COVID-19 Situation in the Region of the Americas. Available from: https://www.paho.org/ en/topics/coronavirus-infections/coronavirus-diseasecovid-19-pandemic

4. Manejo quirúrgico de pacientes con infección por COVID-19. Recomendaciones de la Asociación Española de Cirujanos. Available from: https:// www.aecirujanos.es/files/noticias/152/documentos/ Manejo_quirurgico_v2(1).pdf

5. Aranda-Narváez JM, Tallón-Aguilar L, Pareja-Ciuró F, Martín-Martín G, González-Sánchez AJ, Rey-Simó I, et al. Emergency Surgery and Trauma Care During COVID-19 Pandemic. Recommendations of the Spanish Association of Surgeons [published online ahead of print, 2020 Apr 29]. Cir Esp. 2020; S0009739X (20)30168-8. doi: 10.1016/j.ciresp.2020.04.031

6. American College of Surgeons. COVID-19 and Surgery. Resources for the surgical community. Available from: https://www.facs.org/covid-19

7. Royal College of Surgeon Coronavirus (COVID-19). Guidance for surgeons working during the COVID-19 pandemic. Available from: https://www.rcseng.ac.uk/ coronavirus/joint-guidance-for-surgeons-v1/

8. Tuech JJ, Gangloff A, Di Fiore F, Michel P, Brigand C, Slim $K$, et al. Strategy for the practice of digestive and oncological surgery during the Covid-19 epidemic. 
J Visc Surg. 2020;157(3S1):S7-S12. https://doi. org/10.1016/j.jviscsurg.2020.03.008

9. World Health Organization. Infection prevention and control of epidemic- and pandemic-prone acute respiratorydiseasesinhealthcare.WHOguidelines2007. Available from: httpps://apps.who.int/iris/bitstream/ handle/10665/69707/WHO_CDS_EPR_2007.6_eng. E621C7B090712F27A71A5A5722A8? sequence $=1$

10. Centers for disease Control and Prevention. Coronavirus Disease 2019 (COVID-19) Situation Summary. Available from: http://www.cdc/gov/ coronavirus/2019-ncov/summary.htlm

11. Tien $H C$, Chughtai $T$, Jogeklar $A$, Cooper $A B$, Brenneman $F$. Elective and emergency surgery in patients with severe acute respiratory syndrome (SARS). Can J Surg. 2005;48(1):71-4.

12. Centers for Disease Control and Prevention. Recommended guidance for extended use and limited reuse of $n 95$ filtering facepiece respirators in healthcare settings - NIOSH Workplace Safety and Health Topic. Available from: https://www.cdc. gov/niosh/topics/ hcwcontrols/recommendedguidanceextuse.html

13. Kampf G, Todt D, Pfaender S, Steinmann E. Persistence of coronaviruses on inanimate surfaces and their inactivation with biocidal agents. J Hosp Infect. 2020;104(3):246-51. doi: https://doi.org/10.1016/ j.jhin.2020.01.022.

14. Suen LKP, Guo YP, Tong DWK, Leung PHM, Lung D, $\mathrm{Ng} \mathrm{MSP}$, et al. Self-contamination during doffing of personal protective equipment by healthcare workers to prevent Ebola transmission. Antimicrob Resist Infect Control. 2018; 7:157.

15. Phan LT, Maita D, Mortiz DC, Weber R, Fritzen-
Pedicini, Bleasdale SC, et al. Personal protective equipment doffing practices of healthcare workers. J Occup Environ Hyg. 2019;16(8):575-81.

16. Andonian J, Kazi S, Therkorn J, Benishek L, Billman $C$, Schiffhauer $M$, et al. Effect of an Intervention Package and Teamwork Training to Prevent Healthcare Personnel Self-Contamination During Personal Protective Equipment Doffing. Clin Infect Dis. 2019;69(Suppl 3):S248-S255.

17. Wong J, Goh QY, Tan Z, Lie SA, Tay YC, Ng SY, et al. Preparing for a COVID-19 pandemic: a review of operating room outbreak response measures in a large tertiary hospital in Singapore. Can J Anesth. 2020;67(6):732-45. https://doi.org/10.1007/s12630020-01620-9

18. Cunha A, Peixoto T, Pereira L, Schaun V, Pereira T, et al. How to prepare the operating room for COVID-19 patients. Rev Col Bras Cir. 2020;47: e20202575 DOI: 10.1590/0100-6991e-20202575

19. Lima DS, Ribeiro MAF Jr, Gallo G, Di Saverio S. Role of chest $C T$ in patients with acute abdomen during the COVID-19 era. Br J Surg. 2020;107(7):e196. doi:10.1002/bjs. 11664

20. MIS Filtration Group. How to manage smoke evacuation and filter pneumoperitoneum during laparoscopy to minimize potential viral spread: different methods from SoMe - a video vignette [published online ahead of print, 2020 Apr 23]. Colorectal Dis. 2020;10.1111/ codi.15086. doi:10.1111/codi.15086

21. United States Environmental Protection Agency. Disinfectants for Use against SARS-CoV-2. https:// www.epa.gov/pesticide-registration/list-ndisinfectants-use-against-sars-cov-2
Received in: 30/06/2020

Accepted for publication: 06/07/2020

Conflict of interest: no.

Funding source: none.

\section{Mailing address:}

Carlos Yánez Benítez

E-mail: carlosyb1@gmail.com / drmribeiro@gmail.com 